\title{
The Analysis of the Operative Profit Margin of Trade Companies in Serbia
}

Radojko LUKIC ${ }^{1}$

\begin{abstract}
Both theoretical and practical importance has recently been attached to an analysis of the operating profit margin as a measure of the long-term performance of companies. In the integrated financial reporting it is presented through various indicators based on it. In view of this, we have made a comparative analysis of the operating profit margin and its impact on the performance of trade companies in Serbia and comparable countries. The general conclusion is that it shows a growth tendency and is, nevertheless, lower in comparison to trading companies from countries of a developed market economy. In order to increase the operating profit margin, as a measure of long-term performance, it is necessary to manage the financial structure of the trading companies in Serbia as effectively as possible.
\end{abstract}

Keywords: net profit, interest, tax, depreciation, amortization, financial leverage.

JEL classification: L81, M31, M41, O32

DOI: $10.24818 /$ RMCI.2018.5.458

\section{Introduction}

Considerable theoretical and practical attention has been paid in recent years to analyzing the operating profit margin as a measure of the long-term performance of companies. On the basis of it, special indicators of long-term performance of companies have been developed. They are comparatively analyzed by individual companies (from the same and different sectors) and based on this their long-term business success is recognized. Bearing this in mind, the subject of research in this paper is a comparative analysis of the operational profit margin of retail enterprises in Serbia and comparable foreign retailers. The aim of this research is to thoroughly investigate the problems of the operating profit margin as one of the determinants of the long-term performance of trading companies in Serbia and, on that basis, to propose the measures for its improvement in the future. This gap is to a certain extent filled with this paper, in what we find its scientific and professional contribution.

There is extensive literature written on the subject of general problem of measuring the significance of gross operating margin in financial reporting for the needs of more efficient company management (Sui, 2017). However, a number of

1 Radojko Lukic, Faculty of Economics, University of Belgrade, Belgrade, Serbia, Email: rlukic@ekof.bg.ac.rs 
published papers dedicated to the specificities of gross operating margin analysis in commercial enterprises is significantly lower (Berman, 2013; Levy, 2014; Corona, 2014; Špička, 2016; Tan, 2016; Calva, 2017; Carstea et al, 2017; Ko et al., 2017; Hoe, 2017; Manini, 2017). This particularly applies to literature in Serbia (Lukic, 2017a, b) - as far as we know, there is no complete work that has been published so far on the issue of the importance of measuring and analyzing gross operational margin in Serbia's trade companies.

The basic hypothesis of research in this paper is that the operating profit margin is a significant measure and determinant of the long-term performance of trading companies. For these reasons it is necessary to investigate it more extensively on the example of trade companies in Serbia, particularly the dynamics and factors of its size. With the defined aim and research hypothesis, the basic methodology in this paper is the comparative analysis and application of the relevant statistical analysis. Also, to a certain extent, the historical and normative methodology was applied in researching the treated problem in this paper.

For the needs of the research of the treated problems in this paper, empirical data from the Agency for Business Registers of the Republic of Serbia were used. They are completely comparable to the same type of other global retailers'data and, in this sense, there are almost no restrictions on the obtained research results in this paper due to the fact that we used empirical data from their publicly disclosed financial statements in this study.

\section{Significance and disadvantages of the operational profit margin}

The operating profit margin or earnings before interest, taxes, depreciation and amortization (EBITDA margin) as a measure of performance has been used since the mid-1980s, especially since the 1990s in all companies, including wholesale and retail. Methodologically, it is determined in the following way:

EBITDA $=$ Revenue - Expenses (excluding interest, taxes, depreciation and amortization), i.e.

EBITDA $=$ Net profit + Interest + Tax + Depreciation + Amortization

From this last formula it follows that:

Net profit $=$ EBITDA $-($ Interest + Tax + Depreciation + Amortization $)$

For illustration purposes Table 1 shows the model for calculating the EBITDA margin in the global retailer Walmart. Therefore, it is consistent with the model shown above.

Table 1. Model of calculating the EBITDA margin at Walmart (USD \$ million)

\begin{tabular}{|l|l|l|}
\hline & January 31, 2018 & January 31, 2017 \\
\hline Net income & 9.862 & 13.643 \\
\hline $\begin{array}{l}\text { Add: Net income attributable to non-controlling } \\
\text { interest }\end{array}$ & $661-4.600$ & $650-6.204$ \\
$\begin{array}{l}\text { Less: Income from discontinued operations, net } \\
\text { of income tax }\end{array}$ & & \\
Add: Income tax expense & & \\
\hline
\end{tabular}

Review of International Comparative Management

Volume 19, Issue 5, December 2018459 


\begin{tabular}{|l|l|l|}
\hline & January 31, 2018 & January 31, 2017 \\
\hline Earnings before tax (EBT) & 15.123 & 20.497 \\
\hline $\begin{array}{l}\text { Add: Interest expense, debt, capital lease and } \\
\text { financing obligations }\end{array}$ & 2.330 & 2.367 \\
\hline Earnings before interest and tax (EBIT) & 7.453 & 22.864 \\
\hline Add: Depreciation and amortization & 10.529 & 10.080 \\
\hline $\begin{array}{l}\text { Earnings before interest, tax, depreciation and } \\
\text { amortization(EBITDA) }\end{array}$ & 27.982 & 32.944 \\
\hline
\end{tabular}

Source: available at, https: // www.stock-analysis-on.net, referred on 10/5/2018.

As a measure of long-term performance of retailers, the operating profit margin has its advantages and disadvantages. It is considered that during the usage of this criterion retailers are focused on the performance of fundamental business rather than on financial decision-making related to depreciation of fixed assets, interest and financial structure (lending instead of increasing equity by selling shares) (Levy, 2014). In view of this, it provides bankers, investors, creditors, fiscal authorities and others an insight into the long-term potential options for collecting their retailers' claims. In other words, the operating profit margin as a financial measure is considered to be the best approximation of operating cash flows and therefore a key indicator for managers, bankers, appraisers, analysts and other experts to evaluate the long-term performance of the entities, in our case a retail company. It shows, in the concrete case, what the earnings are realized by the retailer before the interest, taxes, depreciation and amortization with the total invested capital in the business. Negative earnings before interest, taxes, depreciation and amortization are "red alarm" for a retailer and indicate that he is facing serious problems in his business. Under these circumstances, its long-term performance and good business relationships development are unfavorable.

As a measure of long-term performance, operating profit margin has definitely its drawbacks. The way it is calculated, it shows itself "better" than what the actual performance of retailers is, which is not the case with the net profit margin. Retailer can increase the analytical value of performance measurement in "creative way". This is achieved by excessive unnecessary borrowing of foreign capital, excessive acquisition of fixed assets, applying for this purpose the appropriate depreciation method, as well as the development of the so-called "creative accounting" for the purpose of controlling taxable profits. The operating profit margin as a measure does not take into account the impact of working capital (primarily inventories) on the performances of retailers. The impact of working capital on the performance of retailers is very significant since most of their assets relate to working assets, i.e. inventories. This also applies to some other determinants of retailers' performance (such as: the effects of applying new business models, modern concepts of managing cost, customers and product categories; information and communication technologies, etc.).

The EBITDA margin performance indicator can be further developed analytically into indicators such as: EBITDAR (earnings before interest, taxes, 
depreciation, amortization and annuities), and EBITDARM (earnings before interest, taxes, depreciation, amortization, annuities and management), especially when the costs of leasing, restructuring and management represent a significant amount of money. This is typical for retailers, especially with rent, so that all three models (related indicators) can be used in parallel to assess their long-term performance.

More and more financial analysts are aware of certain problems of interpreting the EBITDA margin, and in order to overcome them, the model of economic additional value (the so-called EVA model) is recommended. Nevertheless, it should also be noted that the very model of economic value addition has its own weaknesses, which primarily relate to subjective assumptions regarding the calculation of capital costs. In conclusion, it is necessary to use both models (EBITDA margin, EVA model) concurrently when assessing the long-term performance of retailers. We are well aware of the fact that in recent years many global retailers, and what we consider quite right, also regularly report on the economic value added (for example, METRO group and others) in the context of integrated financial reporting. In this way, the problem of interpreting the EBITDA margin is partially mitigated.

For the purpose of deeper understanding of retailers' long-term performance, a number of indicators that are based on the operating profit margin can be used. They are shown in Table 2 .

Table 2. Key performance indicators for retailers

\begin{tabular}{|l|l|l|}
\hline \multicolumn{1}{|c|}{ Indicators } & \multicolumn{1}{|c|}{ Formula } \\
\hline $\begin{array}{l}\text { Financial } \\
\text { leverage }\end{array}$ & $\begin{array}{l}\text { Financial liabilities } \\
\text { /EBITDA }\end{array}$ & $\begin{array}{l}\text { It shows the coverage of financial liabilities with } \\
\text { earnings before interest, tax depreciation and } \\
\text { amortization, i.e. the ability to generate the related } \\
\text { income from the financial obligations. It is } \\
\text { considered that: if the financial leverage is }>\text { it is no } \\
\text { longer acceptable to banks. }\end{array}$ \\
\hline $\begin{array}{l}\text { Interest } \\
\text { coverage }\end{array}$ & $\begin{array}{l}\text { EBITDA/Interest } \\
\text { coverage }\end{array}$ & $\begin{array}{l}\text { It shows the ability of a (retail company) to cover its } \\
\text { interest costs from its business operations. Obviously, } \\
\text { it is considered that the ratio <1 is unsustainable. }\end{array}$ \\
\hline $\begin{array}{l}\text { Value } \\
\text { multiplication }\end{array}$ & $\begin{array}{l}\text { Enterprise } \\
\text { value/EBITDA } \\
\text { (EV/EBITDA) }\end{array}$ & $\begin{array}{l}\text { It shows how the market values the (retail) firm in } \\
\text { accordance with the ability to generate operational } \\
\text { profits. }\end{array}$ \\
\hline $\begin{array}{l}\text { Performance } \\
\text { indicator }\end{array}$ & $\begin{array}{l}\text { EBITDA/Total } \\
\text { revenue (EBITDA } \\
\text { margin) }\end{array}$ & $\begin{array}{l}\text { These indicators allow comparison of the } \\
\text { performance of the (retail) company with its } \\
\text { competitors. }\end{array}$ \\
\hline $\begin{array}{l}\text { Work } \\
\text { productivity }\end{array}$ & $\begin{array}{l}\text { EBITDA/Number } \\
\text { of employees }\end{array}$ & $\begin{array}{l}\text { It shows how every employee generates earnings } \\
\text { before interest, taxes, depreciation and amortization. }\end{array}$ \\
\hline
\end{tabular}

Note: The table compiled by the author. 
As an illustration, Table 3 shows a value multiplier on the example of a food value chain in the US.

Table 3. Food value chain value multiplier in US, January 5, 2018

\begin{tabular}{|l|l|}
\hline & EV/EBITDA \\
\hline Farm/Agriculture & 13,07 \\
\hline Food processing & 13,01 \\
\hline Food wholesale & 10,43 \\
\hline Retail (grocery and food) & 8,40 \\
\hline Restaurant/Dining & 12,69 \\
\hline
\end{tabular}

Note: Enterprise Value / EBITDA = (Market Value of Equity + Value of Debt-Cash) / EBITDA.

Source: Enterprise Value Multiples by Sector (US), January 5, 2018, available at, http://pages.stern.nyu.edu/ adamodar/New_Home_Page/datafile/vebitda.html, referred on $10 / 5 / 2018$.

The data in a given table show that the value multiplier is different for some members of the food value chain in the US. Thus, for example, it is significantly higher for farming/agriculture (13.07) than for retail (8.49). This is partly due to differences in the very nature of their business.

In order to make in-depth analysis of the EBITDA margins in the food retail sector, table 4 shows a value multiplier of the Wal-Mart retailer and its competitors for 2017 and 2018.

Table 4. Value multiplier,Wal-Mart (January 31, 2017 and 2018)

\begin{tabular}{|l|l|l|l|l|l|l|}
\hline $\begin{array}{l}\text { Wal-Mart Inc., EV / } \\
\text { EBITDA calculation }\end{array}$ & $\begin{array}{c}\text { Jan 31, } \\
\mathbf{2 0 1 8}\end{array}$ & $\begin{array}{c}\text { Jan 31, } \\
\mathbf{2 0 1 7}\end{array}$ & $\begin{array}{c}\text { Jan 31, } \\
\mathbf{2 0 1 6}\end{array}$ & $\begin{array}{c}\text { Jan } \\
\mathbf{3 1} \text { 2015 }\end{array}$ & $\begin{array}{c}\text { Jan 31, } \\
\mathbf{2 0 1 4}\end{array}$ & $\begin{array}{c}\text { Jan 31, } \\
\mathbf{2 0 1 3}\end{array}$ \\
\hline $\begin{array}{l}\text { Enterprise value } \\
\text { (EV), (USD \$ } \\
\text { million) }\end{array}$ & 305.207 & 260.427 & 260.724 & 306.165 & 300.184 & 297.926 \\
\hline $\begin{array}{l}\text { Earnings before } \\
\text { interest, tax, } \\
\text { depreciation and } \\
\text { amortization } \\
\text { (EBITDA), (USD \$ } \\
\text { million) }\end{array}$ & 27.982 & 32.944 & 33.640 & 36.433 & 35.861 & 36.489 \\
\hline Ratio EV / EBITDA & 10,91 & 7,91 & 7,75 & 8,40 & 8,37 & 8,16 \\
\hline $\begin{array}{l}\text { Benchmarking EV / } \\
\text { EBITDA competition }\end{array}$ & & & & & & \\
\hline Amazon.com Inc. & - & 43,74 & 31,40 & 33,08 & 33,45 & 41,58 \\
\hline $\begin{array}{l}\text { Costco Wholesale } \\
\text { Corp. }\end{array}$ & - & 12,63 & 13,27 & 13,49 & 12,08 & 12,30 \\
\hline eBay Inc. & - & 14,50 & 8,04 & 8,92 & 12,34 & 12,88 \\
\hline Home Depot Inc. & 13,46 & 12,90 & 13,23 & 12,90 & 11,11 & 11,74 \\
\hline Lowe's Cos.Inc. & 11,24 & 11,43 & 12,18 & 12,79 & 10,47 & 9,60 \\
\hline
\end{tabular}




\begin{tabular}{|l|l|l|l|l|l|l|}
\hline $\begin{array}{l}\text { Wal-Mart Inc., EV I } \\
\text { EBITDA calculation }\end{array}$ & $\begin{array}{c}\text { Jan 31, } \\
\mathbf{2 0 1 8}\end{array}$ & $\begin{array}{c}\text { Jan 31, } \\
\mathbf{2 0 1 7}\end{array}$ & $\begin{array}{c}\text { Jan 31, } \\
\mathbf{2 0 1 6}\end{array}$ & $\begin{array}{c}\text { Jan } \\
\mathbf{3 1 , 2 0 1 5}\end{array}$ & $\begin{array}{c}\text { Jan 31, } \\
\mathbf{2 0 1 4}\end{array}$ & $\begin{array}{c}\text { Jan 31, } \\
\mathbf{2 0 1 3}\end{array}$ \\
\hline Netflix Inc. & - & 18,03 & 11,80 & 10,59 & 8,22 & 9,62 \\
\hline Target Corp. & 6,96 & 5,59 & 7,47 & 9,21 & 7,85 & 8,09 \\
\hline TJX Cos.Inc. & - & 11,16 & 11,83 & 11,14 & 10,70 & 9,10 \\
\hline EV / EBITDA, Sector & & & & & & \\
\hline General retailers & - & 15,92 & 12,72 & 12,34 & 10,93 & 10,95 \\
\hline $\begin{array}{l}\text { EV / EBITDA, } \\
\text { Industry }\end{array}$ & & & & & & \\
\hline Customer service & - & 12,26 & 11,49 & 10,91 & 10,77 & 10,30 \\
\hline
\end{tabular}

Source: available at, https: // www.stock-analysis-on.net, referred on 28/5/2018.

The data in the given table show that the value multiplier differs between some food retailers. Thus, for example, on January 31, 2018, in Target Corp. it was 6.96 and in Wal-Mart 10.91, respectively. The Wal-Mart value multiplier is lower than the average of the sector and industry. These differences are certainly the result of the implementation of different financial management strategies (lending versus the increase in equity by selling shares).

\section{The dynamics of global retailers' operating profit margin size}

Due to the specifics of the nature itself, way of doing business and the applied financial management strategy, the dynamics of the size of the operating profit margin varies by individual types of trade (wholesale and retail), retail companies and countries in which they operate, retail chains (types of shops) and product categories. This is scientifically proven by the empirical analysis of EBITDA-size dynamics of retailers'margin which has been carried out from different perspectives. In this paper, we will explore the dynamics of the size of EBITDA margin of well-known global retailers, such as Wal-Mart, Tesco and Ahold Delhaize, in order to make comparisons of the EBITDA margin with Serbian trading companies. This provides the basis for proposing adequate measures to increase the size of the EBITDA margin, as a measure of long-term performance of trading companies in Serbia.

Earnings before interest, taxes, depreciation and amortization in retail differ among countries, as shown in Table 5.

Table 5. EBITDA retail margin by individual countries, 2016

\begin{tabular}{|l|l|}
\hline Country & EBITDA margin, 2016 \\
\hline Spain & $1,2 \%$ \\
\hline Europe & $7,3 \%$ \\
\hline North America (USandCanada) & $8,8 \%$ \\
\hline
\end{tabular}

Source: M\&A in the retail and consumer products industry, Valuation multiples, May 2017, 1-36, available at, http://www.ey.com/Publication/vwLUAssets/EY-ma-in-theretail-and-consumer-products-industry-may-2017/\$FILE/EY-ma-in-the-retail-andconsumer-products-industry-may-2017.pdf, referred on 10/5/2018. 
The data in this table show that the EBITDA margin in retail trade is higher in North America (US and Canada) than in Europe. These differences are the result of various general macro and micro business conditions (economic, legal, technological and other), the degree of implementation of innovation in operations, and different business strategies.

Earnings before interest, taxes, depreciation and amortization differ between some sectors of trade. This is shown in Table 6 .

Table 6. EBITDA margin by individual sectors of trade, (1 Q 2018)

\begin{tabular}{|l|l|}
\hline Sector & 1 Q 2018 \\
\hline Car parts & 5,38 \\
\hline Grocery stores & $7,44 \%$ \\
\hline Internet \& mail orders & $9,04 \%$ \\
\hline Retail drugstore & $4,63 \%$ \\
\hline Apparel retail & $10,61 \%$ \\
\hline Technology retail & $5,19 \%$ \\
\hline Home improvement & $14,46 \%$ \\
\hline Restaurant & $22,85 \%$ \\
\hline Retail & $6,05 \%$ \\
\hline Specialty retail & $8,88 \%$ \\
\hline Wholesale & $3,92 \%$ \\
\hline
\end{tabular}

Source: available at, https://csimarket.com/Industry/industry_Profitability_Ratios.php?s $=1300$, referred on 10/5/2018.

The operating profit margin is considerably lower in wholesale than in retail. Likewise, it is lower in retail drugstores than in retail clothing. This is, among other things, the consequence of the way of doing their business.

Earnings before interest, taxes, depreciation and amortization differ among individual retail companies. Table 7 illustrates the dynamics of the EBITDA margin of the global retailer Wal-Mart for the period 2008 - 2017.

Table 7. Dynamics of EBITDA margin of Wal-Mart, 2008 - 2017

\begin{tabular}{|l|l|}
\hline End of period & WMT \\
\hline January 2008 & NA \\
\hline January 2009 & $7,3 \%$ \\
\hline January 2010 & $7,6 \%$ \\
\hline January 2011 & $7,9 \%$ \\
\hline January 2012 & $7,7 \%$ \\
\hline
\end{tabular}




\begin{tabular}{|l|l|}
\hline End of period & WMT \\
\hline January 2013 & $7,7 \%$ \\
\hline January 2014 & $7,5 \%$ \\
\hline January 2015 & $7,5 \%$ \\
\hline January 2016 & $7,0 \%$ \\
\hline October 2016 & $6,8 \%$ \\
\hline January 2017 & $6,8 \%$ \\
\hline October 2017 & $6,6 \%$ \\
\hline
\end{tabular}

Source: available at, https://finbox.io/WMT/explorer/ebitda_margin, referred on 10/5/2018.

Recently, the EBITDA margin has decreased in Wal-Mart compared to the previous period. Compared to some competitors it is larger and compared to others - smaller (for example, Target Corporation 9.9\%) (Table 8). This is, partly, the result of the very nature of the industry operations of its own, sector, company size and business operations model (i.e. the applied financial strategy of the business).

Table 8. EBITDA margin ofWal-Mart and its competitors, 2017

\begin{tabular}{|l|l|}
\hline \multicolumn{1}{|c|}{ Company } & EBITDA margin \\
\hline SpartanNash Company (SPTN) & $-0,3 \%$ \\
\hline Smart \& Final Stores, Inc. (SFS) & $3,1 \%$ \\
\hline Kroger Company (The) (KR) & $4,5 \%$ \\
\hline CompanhiaBrasileira de Distribuicao (CBD) & $6,1 \%$ \\
\hline Caseys General Stores, Inc. (CASY) & $6,2 \%$ \\
\hline Best Buy Co., Inc. (BBY) & $6,2 \%$ \\
\hline CVS Health Corporation (CVS) & $6,6 \%$ \\
\hline Wal-Mart Stores, Inc. (WNT) & $6,6 \%$ \\
\hline Target Corporation (TGT) & $9,9 \%$ \\
\hline Consumer Staples (SECTOR:STPL) & $12,5 \%$ \\
\hline Procter \& Gamble Company (The) (PG) & $25,6 \%$ \\
\hline \#ERROR! (CNCO) & $\mathrm{N}$ \\
\hline
\end{tabular}

Source: available at, https://finbox.io/WMT/explorer/ebitda_margin, referred on 11/5/2018.

Table 9 shows the dynamics of EBITDA margin of Tesco for the period 2014-2018. 
Table 9. EBITDA margin of Tesco, $2014-2018$

\begin{tabular}{|l|l|l|l|l|l|}
\hline $\begin{array}{c}\text { Fiscal year March-February. } \\
\text { All values are expressed in } \\
\text { millions of pounds (GBP) }\end{array}$ & $\mathbf{2 0 1 8}$ & $\mathbf{2 0 1 7}$ & $\mathbf{2 0 1 6}$ & $\mathbf{2 0 1 5}$ & $\mathbf{2 0 1 4}$ \\
\hline Sales/Revenue & 57,491 & 55,917 & 53,933 & 56,925 & 63,557 \\
\hline EBITDA & 2,957 & 2,581 & 2,202 & $(1,733)$ & 4,757 \\
\hline EBITDA growth & $14,57 \%$ & $17,21 \%$ & $227,06 \%$ & $-136,43 \%$ & - \\
\hline EBITDA margin & $5,14 \%$ & - & - & - & - \\
\hline EBIT & 1,663 & 1,284 & - & - & 3,225 \\
\hline
\end{tabular}

Source: available at, https://quotes.wsj.com/UK/XLON/TSCO/financials/annual/incomestatement, referred on 11/5/2018.

The data in the given table show that the share of EBITDA margin in revenues is lower in Tesco (5.14\%) than in Wal-Mart (6.6\%). This is partly a consequence of a different model of doing financial operations.

Table 10 shows the EBITDA margin of Ahold Delhaize, which operates in Serbia as Delhaize Serbia.

Table 10. EBITDA margin of Ahold Delhaize

\begin{tabular}{|l|l|l|l|l|}
\hline & $\mathbf{1 2 / 1 6 A}$ & $\mathbf{1 2 / 1 7 E}$ & $\mathbf{1 2 / 1 8 E}$ & $\mathbf{1 2 / 1 9 E}$ \\
\hline Revenue (€ million) & 63,093 & 63,943 & 65,348 & 66,920 \\
\hline EBITDA (€ million) & 4,142 & 4,267 & 4,507 & 4,836 \\
\hline EBIT (€ million) & 2,420 & 2,386 & 2,638 & 2,923 \\
\hline EBIT growth (\%) & 7,9 & $(1,4)$ & 10,6 & 10,8 \\
\hline EBITDA margin $(\%)$ & 6,6 & 6,7 & 6,9 & 7,2 \\
\hline EBIT margin (\%) & 3,8 & 3,7 & 4,0 & 4,4 \\
\hline EV/EBITDA (x) & 6,7 & 6,4 & 6,0 & 5,5 \\
\hline EV/EBIT $(x)$ & 11,4 & 11,4 & 10,3 & 9,2 \\
\hline
\end{tabular}

Source: available at, https://research-doc.credit-suisse.com/docView?language=ENG\& format $=P D F \&$ sourceid $=$ emgpm \&document_id $=1077229781 \&$ serialid $=7 \% 2 \mathrm{~F} \% 2 \mathrm{~F}$ S9ldDW4ewIdMX6A26zlMtYs6VxLxiTmpgD2zQdGM\%3D, referred on 22/5/2018.

In Ahold Delhaize, the EBITDA margin is higher than at Tesco (5.14\%) and is approximately the same as with Wal-Mart (6.6\%). In the future, there is an estimated growing trend. The EBITDA margin is certainly different among observed countries in which Ahold Delhaize operates. This is shown in Table 11. 
Table 11. EBITDA margin of Ahold Delhaize

by the countries in which it operates, 2018 (in \%)

\begin{tabular}{|l|l|l|l|l|l|l|l|l|}
\hline & \multicolumn{4}{|c|}{ Q1 2018 } & \multicolumn{5}{c|}{ FY 2018 } \\
\cline { 2 - 9 } & Consensus & Min & Max & \#Estimate & Consensus & & Max & \#Estimate \\
\hline USA & $7,3 \%$ & $7,2 \%$ & 7,5 & 13 & $7,2 \%$ & & 7,4 & 1 \\
\hline $\begin{array}{l}\text { The } \\
\text { Netherlands }\end{array}$ & $7,2 \%$ & $7,0 \%$ & $7,4 \%$ & 13 & $7,2 \%$ & $7,1 \%$ & $7,4 \%$ & 13 \\
\hline Belgium & $5,3 \%$ & $4,7 \%$ & $6,0 \%$ & 13 & $5,3 \%$ & $4,6 \%$ & $5,9 \&$ & 13 \\
\hline $\begin{array}{l}\text { Central and } \\
\text { Southeast } \\
\text { Europe }\end{array}$ & $5,7 \%$ & $5,1 \%$ & $6,2 \%$ & 13 & $6,9 \%$ & $5,5 \%$ & $7,1 \%$ & 12 \\
\hline $\begin{array}{l}\text { Total Ahold } \\
\text { Delhaize }\end{array}$ & $6,9 \%$ & $6,7 \%$ & $7,0 \%$ & 14 & $6,9 \%$ & $6,7 \%$ & $7,0 \%$ & 14 \\
\hline
\end{tabular}

Source: available at, https://www.aholddelhaize.com/media/6780/consensus-ahold-delhaizepre-q1-2018.pdf, referred on 11/5/2018.

Ahold Delhaize's operating profit margin, observed by individual countries in which it operates, is significantly higher in the US and the Netherlands than in Belgium and Central and Southeastern Europe (to which the Delhaize Serbia belongs). These differences are the result of different general business conditions and applied (financial) business strategies.

Table 12 shows the EBITDA margin of the Russian company X5 Retail Group for the period 2012-2016.

Table 12. Dynamics of EBITDA margin of the company X5 Retail Group, 2012-2016

\begin{tabular}{|l|l|l|}
\hline & EBITDA Margin (Rub bn) & EBITDA margin, \% \\
\hline 2012 & 35,1 & $7,1 \%$ \\
\hline 2013 & 38,4 & $7,2 \%$ \\
\hline 2014 & 46,4 & $7,3 \%$ \\
\hline 2015 & 59,4 & $7,3 \%$ \\
\hline 2016 & 79,5 & $7,7 \%$ \\
\hline $2016 / 2015$ & $33,8 \%$ & \\
\hline
\end{tabular}

Source: Q1 2017 Financial Results, X5 Retail Group, Moscow, Russian Federation 27 March 2017, available at, https://www.x5.ru/en/Documents/X5-Q1-2017Financial-results.pdf, referred on 12/5/2018.

The data in the given table clearly show that the EBITDA margin of the company X5 Retail Group is higher than in Wal-Mart, Tesco and Ahold Delhaize. In other words, its profitability measured by cash flows from operations (using EBITDA margin) is slightly better than the observed retail companies. 


\section{Dynamics of the size of the operating profit margin of trading companies in Serbia}

Under the influence of different factors, the dynamics of the size of the operating profit margin of trading companies in Serbia varies from comparable global retailers in various countries. Table 13 shows the dynamics of the EBITDA margin of trading companies in Serbia for the period 2013-2017.

Table 13. Dynamics of size of EBITDA margin of trading enterprises in Serbia, 2013-2017

\begin{tabular}{|l|l|l|l|l|l|}
\hline & $\begin{array}{c}\text { Net profit } \\
\text { (million } \\
\text { dinars) }\end{array}$ & $\begin{array}{c}\text { Interest } \\
\text { (million } \\
\text { dinars) }\end{array}$ & $\begin{array}{c}\text { Tax } \\
\text { (million } \\
\text { dinars) }\end{array}$ & $\begin{array}{c}\text { Amortization } \\
\text { (million } \\
\text { dinars) }\end{array}$ & $\begin{array}{c}\text { EBITDA margin } \\
\text { (million dinars) }\end{array}$ \\
\hline 2013 & 89.730 & 23.864 & 10.647 & 29.314 & 153.555 \\
\hline 2014 & 86.955 & 25.162 & 9.566 & 30.558 & 152.241 \\
\hline 2015 & 95.265 & 20.693 & 14.063 & 32.116 & 162.137 \\
\hline 2016 & 102.002 & 15.160 & 16.115 & 35.055 & 168.332 \\
\hline 2017 & 126.734 & 15.383 & 17.496 & 36.318 & 195.931 \\
\hline $\begin{array}{l}\text { Descriptive } \\
\text { Statistics }\end{array}$ & & & & & \\
\hline Minimum & 86955,00 & 15160,00 & 9566,00 & 29314,00 & 152241,00 \\
\hline Maximum & 126734,00 & 25162,00 & 17496,00 & 36318,00 & 195931,00 \\
\hline Mean & 100137,2000 & 20052,4000 & 13577,4000 & 13577,4000 & 166439,2000 \\
\hline $\begin{array}{l}\text { Std. } \\
\text { Deviation }\end{array}$ & 15942,75534 & 4657,93810 & 3417,20724 & 3417,20724 & 17744,36091 \\
\hline $\begin{array}{l}\text { Valid N } \\
\text { (listwise) }\end{array}$ & 5 & 5 & 5 & 5 & 5 \\
\hline $\begin{array}{l}\text { (CAGR } \\
\text { Compound } \\
\text { Annual } \\
\text { Growth } \\
\text { Rate) }\end{array}$ & $7,15 \%$ & $-8,41 \%$ & $10,44 \%$ & $4,38 \%$ & $4,99 \%$ \\
\hline $\begin{array}{l}\text { Note: The } \\
\text { MBITDA }\end{array}$ & & & & & \\
\hline
\end{tabular}

Note: The EBITDA margin calculated by the author and descriptive statistics performed with the application of theSPSS software. The formula for calculating CAGR is: $\mathrm{CAGR}=(\mathrm{EV} / \mathrm{SV})^{1 / \mathrm{n}}-1$ where: $\mathrm{EV}=$ Investment end value, $\mathrm{SV}=$ Investment initial value and $\mathrm{n}=$ Number of investment periods (month, year, etc.).

Source: Business Registers Agency Belgrade.

The data in the given table show that the dynamics of EBITDA size of trading companies in Serbia increased in the observed period from year to year, except in 2014. In the analyzing period it amounted166.439 million dinarson average. In trade companies in Serbia, the EBITDA margin was above average in the last two years (2016 and 2017) of the observed period. The annual growth rate of EBITDA margin of trading companies in Serbia is $4.99 \%$. The annual growth rate of its components is: net profit $7,15 \%$, interest $(-8,41 \%)$, tax $10,44 \%$, and amortization $4,38 \%$, which reflected on the long-term performance (measured by 
EBITDA margin) of trading companies in Serbia. In line with the recent growing EBITDA margin trend, the conclusion is that the long-term performance of trading companies in Serbia has improved. Nevertheless, they are worse than global retailers from countries in a developed market economy.

Table 14 shows key indicators and descriptive statistics in order to gain a better understanding of the significance and size of the EBITDA margin of trade companies in Serbia for the period 2013-2017.

Table 14. Key performance indicators for trade companies in Serbia, 2013-2017

\begin{tabular}{|l|l|l|l|l|}
\hline & $\begin{array}{c}\text { Financial } \\
\text { liabilities/ } \\
\text { EBITDA }\end{array}$ & $\begin{array}{c}\text { EBITDA/ } \\
\text { Interest costs }\end{array}$ & $\begin{array}{c}\text { EBITDA/ } \\
\text { Total } \\
\text { revenue, \% }\end{array}$ & $\begin{array}{c}\text { EBITDA/Number } \\
\text { of employees } \\
\text { (thousand dinars) }\end{array}$ \\
\hline 2013 & 9,20 & 6,43 & 5,13 & 794,757 \\
\hline 2014 & 9,17 & 6,05 & 5,08 & 796,356 \\
\hline 2015 & 8,59 & 7,83 & 5,26 & 828,832 \\
\hline 2016 & 8,61 & 11,10 & 4,95 & 816,780 \\
\hline 2017 & 7,45 & 12,73 & 5,50 & 941,885 \\
\hline $\begin{array}{l}\text { Descriptive } \\
\text { Statistics }\end{array}$ & & & & \\
\hline Minimum & 7,45 & 6,05 & 4,95 & 794,76 \\
\hline Maximum & 9,20 & 12,73 & 5,50 & 941,89 \\
\hline Mean & 8,6040 & 8,8280 & 5,1840 & 835,7220 \\
\hline Std. Deviation &, 70843 & 2,95175 &, 20864 & 61,04234 \\
\hline $\begin{array}{l}\text { Valid N } \\
\text { (listwise) }\end{array}$ & 5 & 5 & 5 & 5 \\
\hline
\end{tabular}

Note: The given indicators calculated and descriptive statistics performed by the author with the application of the SPSS software.

Source: Business Registers Agency Belgrade.

The average operating profit margin of trade companies in Serbia, expressed in percentage of revenue, is slightly higher than 5\% (Mean 5,1840). This means that it is lower than in the US, Canada, Europe, the Netherlands, Belgium, Central and Southeast Europe, Germany and Russia. For the purpose of a more complex analysis, Table 15 shows the correlation analysis of performance indicators, which are carried out on the basis EBITDA margin of trade enterprises in Serbia. 
Table 15. Correlation analysis of the performance indicators of trade companies in Serbia

\begin{tabular}{|c|c|c|c|c|c|}
\hline \multicolumn{6}{|l|}{ Correlations } \\
\hline & & $\begin{array}{l}\text { Financial } \\
\text { liabilities/ } \\
\text { EBITDA }\end{array}$ & $\begin{array}{c}\text { EBITDA/ } \\
\text { Interest costs }\end{array}$ & $\begin{array}{c}\text { EBITDA/ } \\
\text { Total } \\
\text { revenue, \% }\end{array}$ & \begin{tabular}{|c|} 
BITDA/ \\
Number of \\
employees \\
(thousand dinars)
\end{tabular} \\
\hline \multirow{3}{*}{$\begin{array}{l}\text { Financial } \\
\text { liabilities/ } \\
\text { EBITDA }\end{array}$} & $\begin{array}{l}\text { Pearson } \\
\text { Correlation }\end{array}$ & 1 &,$- 894^{*}$ &,- 775 &,$- 978^{* *}$ \\
\hline & Sig. (2-tailed) & &, 041 & 14 &, 004 \\
\hline & $\mathrm{N}$ & 5 & 5 & 5 & 5 \\
\hline \multirow{3}{*}{$\begin{array}{l}\text { EBITDA/ } \\
\text { Interest costs }\end{array}$} & $\begin{array}{l}\text { Pearson } \\
\text { Correlation }\end{array}$ &,$- 894^{*}$ & 1 & ,424 &, 813 \\
\hline & Sig. (2-tailed) &, 041 & & 477 &, 095 \\
\hline & $\mathrm{N}$ & 5 & 5 & 5 & 5 \\
\hline \multirow{3}{*}{$\begin{array}{l}\text { EBITDA/ } \\
\text { Total revenue, } \\
\%\end{array}$} & $\begin{array}{l}\text { Pearson } \\
\text { Correlation }\end{array}$ &,- 775 &, 424 & 1 &, 859 \\
\hline & Sig. (2-tailed) &, 124 &, 477 & &, 062 \\
\hline & $\mathrm{N}$ & 5 & 5 & 5 & 5 \\
\hline \multirow{3}{*}{$\begin{array}{l}\text { EBITDA/ } \\
\text { Number of } \\
\text { employees } \\
\text { (thousand } \\
\text { dinars) }\end{array}$} & $\begin{array}{l}\text { Pearson } \\
\text { Correlation }\end{array}$ &,$- 978^{* *}$ &, 813 &, 859 & 1 \\
\hline & Sig. (2-tailed) &, 004 &, 095 &, 062 & \\
\hline & $\mathrm{N}$ & 5 & 5 & 5 & 5 \\
\hline \multicolumn{6}{|c|}{ *. Correlation is significant at the 0.05 level (2-tailed). } \\
\hline
\end{tabular}

Note: Calculation performed by the author with the application of the SPSS software program.

Source: Business Registers Agency, Belgrade.

Correlation analysis shows that there is a strong negative correlation between the EBITDA / Total Revenue (\%) and the Indicators of Financial Liabilities / EBITDA, but not at the level of statistical significance. There is a weak correlation between the EBITDA / Total Revenue (\%) and EBITDA / Interest Rates, and is not at the level of statistical significance. There is a strong correlation between EBITDA / Total Revenue (\%) and EBITDA / Number of employees but also not at the level of statistical significance. Between the indicators of financial liabilities / EBITDA and EBITDA / Interest costs there is a strong negative correlation on the level of statistical significance. Based on the given correlation, it can be concluded that more efficient management of the financial structure of capital (financial leverage $=$ assets $/$ capital) can influence on the improvement of the return on sales measured by the relationship between EBITDA and total revenues. This also applies to revenue, costs and profit management.

Due to its importance, we will especially consider the impact of the costs of goods sold, as a characteristic investment measure, on the EBITDA margin of 
trading companies in Serbia. Table 16 shows the costs of goods sold by trade companies in Serbia for the period 2013 - 2017.

Table 16. Cost of goods sold by trade companies in Serbia, 2013 - 2017

\begin{tabular}{|l|l|l|}
\hline & $\begin{array}{l}\text { Cost of goods sold, } \\
\text { (million dinars) }\end{array}$ & $\begin{array}{l}\text { Cost of goods sold in } \\
\text { return on sales, (\%)* }\end{array}$ \\
\hline 2013 & 2.300 .147 & 76,98 \\
\hline 2014 & 2.288 .700 & 76,40 \\
\hline 2015 & 2.350 .737 & 76,36 \\
\hline 2016 & 2.590 .399 & 76,31 \\
\hline 2017 & 2.705 .077 & 75,95 \\
\hline Descriptive Statistics & & \\
\hline Mean & 2447012,0000 & \\
\hline Std. Deviation & 189115,22228 & \\
\hline N & 5 & \\
\hline $\begin{array}{l}\text { (CAGR - Compound Annual } \\
\text { Growth Rate) }\end{array}$ & $3,3 \%$ & \\
\hline
\end{tabular}

Note: *Calculations and descriptive statistics performed by the author with the application of SPSS software.

Source: Business Registers Agency, Belgrade.

The data in the given table show that in the observed period the average cost of sold goods amounted to 2,447,012 million dinars. The average share of costs of goods sold in total revenues was $76.40 \%$. In other words - the average gross margin of trade companies in Serbia in the given period was $23.60 \%(100-76.40=$ 23.60), from which the operating costs were covered and the target profit was realized. In the analyzed period, the costs of goods sold by trade companies in Serbia have slightly increased dynamically until 2015 and from that year up to 2017 much faster, as can be seen from Figure 1. The annual growth rate of the costs of goods sold (3.3\%) is thus lower than the annual growth rate of the EBITDA margin (4.99\%).To sum up, the return on investments in Serbia's trade companies increased to some extent. 


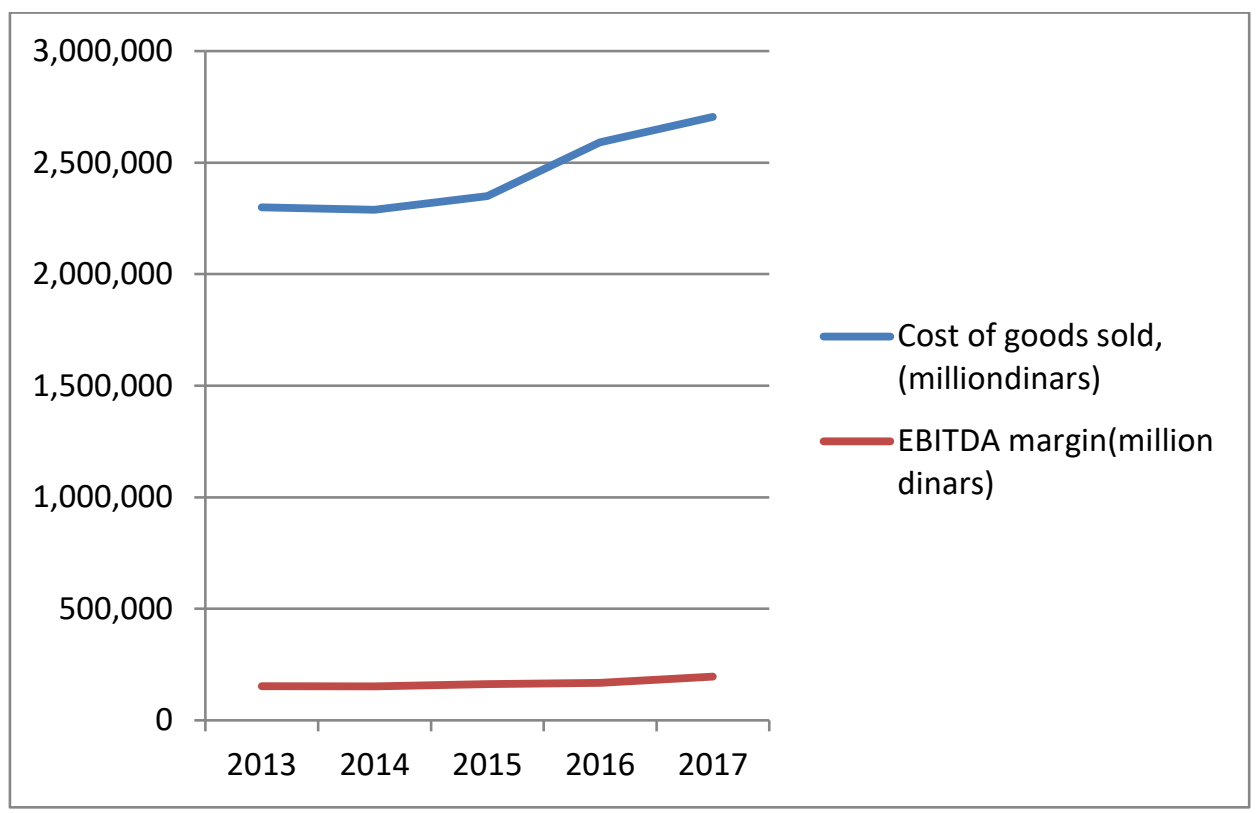

Figure 1. Cost dynamics of goods sold and EBITDA margin of trade companies in Serbia

Note: Figure illustrated by the author.

Source: Business Registers Agency.

Table 17 shows the correlation analysis between costs of goods sold and EBITDA margin of trade companies in Serbia for the period 2013 - 2017.

Table 17. Correlation analysis of costs of the goods sold and EBITDA margin of trading companies in Serbia

\begin{tabular}{|l|l|l|l|}
\hline \multicolumn{2}{|l|}{ Correlations } & EBITDA margin & Costs of goods sold \\
\hline \multirow{2}{*}{ Pearson Correlation } & EBITDA margin & 1,000 &, 927 \\
\cline { 2 - 4 } & Costs of goods sold &, 927 & 1,000 \\
\hline \multirow{3}{*}{ Sig. (1-tailed) } & EBITDA margin & &, 012 \\
\cline { 2 - 4 } & Costs of goods sold &, 012 & \\
\hline \multirow{2}{*}{$N$} & EBITDA margin & 5 & 5 \\
\cline { 2 - 5 } & Costs of goods sold & 5 & 5 \\
\hline
\end{tabular}

Note: Calculation performed by the author with the application of the SPSS software. Source: Business Registers Agency. 
The data in the given table show that the costs of goods sold, as a specific expression of investment, significantly affect the EBITDA margin (Pearson Correlation, 927, Sig. (1-tailed), $012 \mathrm{p}<0.05$ ). (The regression equation is: $\mathrm{Y}=$ $46285.142+0.087 \mathrm{X}$, where: $\mathrm{Y}=$ EBITDA margin, and $\mathrm{X}=$ costs of goods sold.)

The method of financing working capital (especially inventories) is a significant determinant of the EBITDA margin of trading companies. In this context, we will examine the impact of interest costs on the costs of goods sold of the commercial enterprises in Serbia. The results of the correlation analysis show that there is a negative (statistically significant) strong correlation between the costs of sold goods and interest as a component of the EBITDA margin of trading enterprises in Serbia (Table 18) - this is quite logical - given their character.

Table 18. Correlation analysis of costs of goods sold and interest

\begin{tabular}{|c|c|c|c|}
\hline \multicolumn{4}{|l|}{ Correlations } \\
\hline & & Costs of goods sold & Interest \\
\hline \multirow{3}{*}{ Costs of goods sold } & Pearson Correlation & 1 &,$- 947^{*}$ \\
\hline & Sig. (2-tailed) & &, 015 \\
\hline & $\mathrm{N}$ & 5 & 5 \\
\hline \multirow{3}{*}{ Interest } & Pearson Correlation &,$- 947^{*}$ & 1 \\
\hline & Sig. (2-tailed) &, 015 & \\
\hline & $\mathrm{N}$ & 5 & 5 \\
\hline
\end{tabular}

Source: Business Registers Agency, Belgrade.

The conclusion is that more efficient management of the costs of goods sold (including operating costs, interest rates) can significantly influence the increase in the EBITDA margin as a measure of the performance of trading companies in Serbia. This also applies to the most efficient management of their assets, financial capital structure, revenues and profit.

In order to make anin-depth analysis of long-term trade performance in Serbia measured by the EBITDA margin, we will show the respective margin for three significant trade companies in Serbia for 2016 (Table 19).

Table 19. EBITDA margin of significant trade companies in Serbia, 2016

\begin{tabular}{|l|l|l|}
\hline & \multicolumn{1}{|c|}{$\begin{array}{c}\text { EBITDA margin, } \\
\text { (million dinars) }\end{array}$} & \multicolumn{1}{|c|}{$\begin{array}{c}\text { EBITDA margin, } \\
\text { (\% from sales) }\end{array}$} \\
\hline Ahold Delhaize Serbia & 3.719 & $4,3 \%$ \\
\hline Mercator-S & 3.081 & $2,9 \%$ \\
\hline IDEA & 117 & $3,99 \%$ \\
\hline
\end{tabular}

Note: Author's calculation.

Source: Business Registers Agency, Belgrade. 
Based on the data presented in the given table, we can also conclude that the EBITDA margin of the leading trading companies in Serbia is lower than the analyzed comparable retail trade companies from the developed market economies. It points to the conclusion that it is necessary to efficiently manage revenues, costs, profit, assets, financial structure in order to improve the performance of trading companies in Serbia in the future. Due to that fact, as well as a prominent theoretical and practical importance, it is necessary to empirically analyze the dynamics of the size of the operating profit margin of trading companies in Serbia in the future and to take appropriate measures for its increase.

\section{Conclusion}

Due to the growing EBITDA margin trend and based on the analysis conducted in this paper, we can conclude that the long-term performance of trade companies in Serbia has recently improved. The average operating profit margin (EBITDA) of trading companies in Serbia expressed as percentage of revenue is slightly higher than 5\% (Mean 5.1840). However, it is lower compared to the US, Canada, Europe, the Netherlands, Belgium, Central and Southeast Europe, Germany and Russia. More efficient management of the financial structure of capital (financial leverage $=$ assets $/$ capital) can influence the improvement of the return on sales measured by the relationship between the EBITDA margin and total revenues. Costs of goods sold, as a specific expression of the size of investments, significantly affect the EBITDA margin (Pearson Correlation, 927, Sig. (1-tailed), $012 \mathrm{p} \mathrm{<0.05).} \mathrm{There} \mathrm{is} \mathrm{negative} \mathrm{(but} \mathrm{statistically} \mathrm{significant)} \mathrm{strong} \mathrm{correlation}$ between the costs of goods sold and interest as a component of the EBITDA margin, which is quite logical given their character. The EBITDA margin of the analyzed leading trading companies in Serbia (Ahold Delhaize Serbia, Merctor-S and IDEA) is lower than that of analyzed comparable retail (primarily food) trade companies from the developed market economies. Overall, more efficient management of the financial structure of capital, sales revenues, costs of goods sold (including operating costs, interest) and profit can significantly influence the increase in the EBITDA margin as a measure of the long-term performance of trading companies in Serbia. This will definitely have a positive impact on the dynamics of the size and efficiency of investments, as a key factor in the performance of trade companies in Serbia. 


\section{References}

Berman.B. and Evans. J. R. (2013). Retail Management Boston: Prentice Hall.

Calva, A. (2017). Case of financial ratio analysis: Food retail industry in Canada (2012 - 2016) .Acus Consulting Ltd., 1-13, available at, www.Acus Consulting.com, referred on 3/5/2018.

Carstea, G., Corbos, R.A., Popescu, R.I. and Bunea, O.I. (2017). Analysis of the influence of some indicators on the profitability of the FMCG retail market in Romania. Proceedings of the 11th International Management Conference „The Role of Management in the Economic Paradigm of the XXI Century", November 2nd-4th, Bucharest, Romania, 481-492.

Corona, R. (2014) .Comparative Analysis of Major US Retailers Based on Enterprise Marketing Efficiency. Global Business research, 8(4), 25-39.

Hoe, L.W., Siew; L.W., Wai, C.J. (2017). A Study on the Performance of the Retailers in Malaysia with TOPSUS Model. International Journal of Economic Theory and Application, 5(1), 7-12.

Ko, K., Chang, M., Bae, E.S. and Kim, D. (2017). Efficiency Analysis of Retail Chain Stores in Korea. Sustainability, 9(9), 16-29, available at,

https://doi.org/10.3390/su9091629, referred on 10/5/2018.

Levy, M. Weitz. B. A. and Grewal. D. (2014). Retailing Management. New York: McGraw-Hill.

Lukic, R. (2017a). The Impact of Margin on the Performance of Trade Companies in Serbia.LIMES plus: Journal of Social Sciences and Humanities, 3, 4971.

Lukic, R. and Sokic, M. (2017b). Efficiency Analysis of Trade Capital Management in Serbia. Management Research and Practice, 9(4), 38-47.

Manini, R. and Amat, O. (2017) .Credit Scoring for the Supermarket and Retailing Industry: Analysis and Application Proposal. European Accounting and Management Review, 4(1), 75-88.

Sui, Y. (2017) .The Research on the Applications and Limitations of EBITDA. 2017 2nd International Conference on Sustainable Energy and Environment Protection (ICSEEP 2017), 66-69.

Špička, J. (2016) .Market Concentration and Profitability of the Grocery Retailers in Central Europe. Central European Business Review, 5(3), 5-24.

Tan, Z. (2016) .Application of Discounted Cash Flow Model Valuation - WalMart. MPRA Paper No. 83903, 1-16, available at, https://mpra.ub.unimuenchen.de/83903/1/MPRA_paper_83903.pdf, referred 3/5/2018. 